\title{
Making Histories
}

The Meeting of German and British Descendants of First World War Veterans in "No Man's Land," Bavaria, 2016

Rachel Duffett and Michael Roper

ABSTRACT: This article reflects upon a Heritage Lottery-funded project devised by Britain's leading practitioner of reminiscence arts, Age Exchange. "Meeting in No Man's Land" explored the different family legacies of the First World War by bringing together the British and German descendants of its veterans. ${ }^{1}$ The project process had many similarities to the practice of oral history, but there were also significant differences. This article considers the shared territory of the two methodologies while at the same time acknowledging the uniqueness of Age Exchange's approach to the making of histories.

KEY WORDS: First World War commemoration, reminiscence arts, oral history, family legacies

Sitting in a sunny room in Rosenheim, Germany, on April 8, 2016, listening to Ruth and Linde sharing memories of their veteran fathers should not have been too far distant from the usual activities of First World War historians. The men had, in I9I7, faced each other at Ypres, and now their daughters-with a combined age of almost I70 years-sat side by side in Bavaria swapping memories and showing precious photos and letters. An intimacy quickly developed between the pair, signaled by the mutual recognition of their fathers' vulnerabilities: comparing photos, they remarked on how young, and how small, each was; not men, in fact, but boys. Ruth spoke of the loss of her father twelve years after the war when she was four, of the invalid that he had become as a result of gassing, and of her memories of him as a slipper-clad patient. That image fell away when she read one of the love letters that he had sent her mother from the Western Front-here was a vital and passionate young man, longing to be with his fiancée and looking forward to a life together far

I A companion article to this piece explores the different motivations that draw individuals into such projects. Michael Roper and Rachel Duffett, "Family Legacies in the Centenary: Motives for First World War Commemoration among British and German Descendants," History and Memory (forthcoming).

THE PUBLIC HISTORIAN, Vol. 4O, No. I, pp. I3-34 (February 20I8). ISSN: 0272-3433, electronic ISSN 1533-8576. (C) 2018 by The Regents of the University of California and the National Council on Public History. All rights reserved. Please direct all requests for permission to photocopy or reproduce article content through the University of California Press's Reprints and Permissions web page, http://www.ucpress.edu/journals.php?p=reprints. DOI: https://doi.org/Io.I525/tph.20I8.4O.I.I3. 
away from the dreadfulness of war. Written by a young man and read by an elderly woman almost a century later, the letter provided a continuity that bridged time and space: the circle of author and recipient was completed in the reader, their daughter.

Another circle seemed to be completed in the attentiveness of Linde, whose concern and sensitivity was evidence of a very different relationship between the two nations one hundred years on. Her father had returned from the war physically intact, although his exaggerated sense of order and vigorous disciplining of his children spoke of a domestic life that had been shaped by the military experience of his youth. She had brought with her an extensive collection of postcards he had sent to his parents from Belgium and France in which the destruction of war featured frequently. Scenes of broken churches and rubble-piled streets provided the medium for communication with home, for requests for winter underwear and descriptions of Sunday dinners-“soup, roast meat and green salad." The women shared their stories, held fragments of each other's family pasts, and talked about not just their fathers' war experiences, but about how the war had seeped into their own lives through their paternal relationships-or absence of them. There was humor; the German elder showed her father's service record book, which listed his scores at the rifle range-very low!-and said that his British opponent was probably lucky to be opposite such a poor shot. There was also a loving concern, expressed as a deep desire to understand each other's lives, to look together at not just a divided past but to a united future.

Stories of the war do not lose their power to move because of their sheer number. The soldiers' pocket diaries that end on June 30, I9I6 (the eve of the First the Battle of the Somme), or the letters home, whose very inarticulacy can be the source of their profound affect, all have an impact on the researcher who does not become inured to the individual tragedies through reading iterations of suffering. As First World War historians who had been invited to observe Age Exchange's (AE) project funded by the Heritage Lottery Fund (HLF) on the legacies of the war in Britain and Germany, we were familiar with sources and narratives of the conflict and their affective force. Yet, there was something unusual about the encounter in Bavaria, this "Meeting in No Man's Land" (MINML) as, a hundred years on from the first Christmas truces, the project had been named. It had a particular emotional power and generated reactions in its observers that felt different from those typically experienced in historical study. AE's project brought together the descendants of veterans in order to explore the different legacies of the First World War in British and German families. But in addition to the explicit objectives we found that it had a further impact, raising questions about how we make history, how personal stories are shared, captured, and communicated, and the nature of the relationship between practitioners and their subjects.

$\mathrm{AE}$ is Britain's leading exponent of reminiscence and much of its work would be wholly recognizable to oral historians. We had been invited to participate in the project because of the parallels with our current research on the family legacies of the war and connections fostered during AE's preceding project, "Children of the 
Great War" (COTGW). The ground felt in some ways familiar, yet in other aspects it was different from the kind of historical research we are used to and we found ourselves in a rather different country. Most significantly, the process itself and the emotional engagement that MINML engendered in its participants and observers impeded the maintenance of a distance from the subjects and the material that is the usual requirement for research. ${ }^{2}$ The concept of "no man's land" was central to AE's project, a neutral space in which the descendants of veterans met to jointly negotiate their family legacies of the conflict, and it felt as if this liminal quality might also be applied to the space in which AE's practices operated. The connections between oral history and reminiscence work are evident; the former provided the original framework within which reminiscence therapy was developed. ${ }^{3}$ Any clear division that may have existed when reminiscence work foregrounded its therapeutic possibilities and when oral history was less focused on subjectivities and the role of interviewees in the process has long since been eroded. In many ways, MINML was an oral history project, but there were differences, not least the generation of a level of affect which drew not just the participants but also the organizers and observers into its orbit. It was the collective format that felt so unusual. There were individual interviews, but they were just part of a wider set of processes that engaged the participants, organizers, and observers who were living and socializing together for five days in Bavaria. This sharing of space, experience, and memory had the effect of creating a group dynamic that differed from the more usual process of making history where the historian interviews a series of subjects individually before using this and other material to formulate a response to a specific research question. In MINML, the distance necessary to perform that reflection was harder to achieve, not only emotionally because of the nature of the collective experience, but also in temporal terms as the main output from the project, a film, was being made simultaneously, effectively combining the research and a significant part of the production stages.

MINML was a unique history project, from its international basis through its collective processes to its outputs. This article will describe its planning and execution and will explore the uncharted space in which it operated in order to consider the project in the context of more traditional reminiscence therapy and oral history practices. We hope it will also convey its uniqueness in the way in which it occupied its own powerful version of no man's land within the complex and diverse world of history making.

\section{Age Exchange and Reminiscence}

$\mathrm{AE}$ has its roots in the radical community work Pam Schweitzer undertook in southeast London in I982. As an education officer for a voluntary organization, Task

2 See, for example, Mark Salber Phillips, "Distance and Historical Representation," History Workshop Journal 57, no. I (January 2004): I23-4I.

3 Lynn Abrams, Oral History Theory (Abingdon, UK: Routledge, 2010), 158-59. 
Force, her role was to engage young people in delivering practical support to the elders in their communities, but exposure to a Greenwich reminiscence project triggered her interest in the social, communal, and dramatic possibilities of transmitting stories across generations. ${ }^{4}$ The project used "Recall" packages created by the charity Help the Aged to formulate a series of activities that enabled a group of care home (assisted living) residents to remember and share anecdotes from their pasts. The charity's initiative was an acknowledgement of the potential of reminiscence work, chiefly identified by Robert Butler in the late ig6os who recognized the way in which reminiscence could act therapeutically as a method for creating informal life reviews. ${ }^{5}$ Previously, there was a distinct lack of enthusiasm for reminiscence activity, resulting from an Aristotelian view that condemned the old for living through memories of the past rather than with hope for the future. ${ }^{6}$ Six main categories of reminiscence-integrative, instrumental, narrative, transmissive, escapist, and obsessive-were identified, and some of the contributions made to the MINML project exhibited traits of these forms. Briefly, the chief function of integrative reminiscence is to reconcile oneself with the past and to achieve a sense of coherence with regard to painful events, while in its instrumental form it empowers the subject through drawing upon memories of the successful resolution of problems. The revisiting of successful coping strategies provides a mechanism through which the pressure of current issues can be relieved. Narrative reminiscence reflects the desire to pass important stories on, but in a mainly factual manner, and so it differs from the transmissive form in which the recounting of events is linked with the desire to pass on "cultural ideals and personal wisdom." Escapist reminiscence serves to mitigate the stresses of aging and decline through the reliving of past glories, and the inability to stop endlessly repeating the same stories and events is categorized obsessive. ${ }^{7}$

Schweitzer recognized the power in the reminiscence process and the opportunities that forms of social work offered as spaces where it might be employed. She began to engage the young with the old not through the mechanics of gardening and shopping as had been originally planned, but through their physical enactment of the memories of youth recalled many years later. In 1983, Schweitzer founded the Age Exchange Theatre Trust and recruited professional actors to help her collect the reminiscence material from elders focused on themes of particular

4 Pam Schweitzer, "Making Memories Matter: Reminiscence and Creativity: A Thirty-Year Retrospective," Oral History 4I, no. I (Spring 2013): 85.

5 Robert Butler, "The Life Review: An Interpretation of Reminiscence in the Aged," Psychiatry 26, no. I (February 1963): 65-76, cited in Schweitzer, "Making Memories," 85.

6 Peter Coleman, "Reminiscence within the Study of Ageing: The Social Significance of Story," in Reminiscence Reviewed, ed. Joanna Bornat (Buckingham, UK: Open University Press, 1994), Io.

7 Paul T. P. Wong and Lisa M. Watt, "What Types of Reminiscence Are Associated with Successful Aging?," Psychology and Aging 6, no. 2 (199I): 272-79. Doubts have been raised regarding the integrative functions of reminiscence work and its ability to use memories to strengthen those subjects who are "mentally frail." See Joanna Bornat, "Oral History as a Social Movement: Reminiscence and Older People," in The Oral History Reader, ed. Robert Perks and Alistair Thomson (London: Routledge, 1998), 196. 
historical or social importance. These raw sources were then shaped into a script that mainly consisted of verbatim dialogue from the original group work or interviews. The script formed the basis for a dramatic performance, enhanced by a musical accompaniment and a discussion with the audience afterwards when further memories could be shared. The transformation of the memories into theater was, Schweitzer believed, important not only in terms of sharing social history that had the power to enrich communities, but also because it helped the elders to become "more visible and more valued" and provided opportunities for crosscultural encounters that would not otherwise have arisen. ${ }^{8}$ The establishment of the Age Exchange Reminiscence Centre in Blackheath, London, in 1987 reflected the success of the organization's activities, as did the twenty-five thousand visitors who came each year throughout the rg9os from both the United Kingdom and abroad to learn about the nonprofit's work. ${ }^{9}$ Thirty years on, AE embarked on its MINML project, an enterprise that in many ways followed in the honorable traditions of the organization, but also embraced a set of new challenges.

\section{Meeting in No Man's Land-The Project}

The aim of MINML was to bring together German and British elders to share their family histories and to produce a film and resources for schools based on the meeting. The full-length documentary film would be presented at venues in Britain and Germany, and it would also provide a wealth of visual material that could be used as a resource for the creation of apps for use by pupils to help them explore the different national legacies of the war. AE was aware from its contact with several London schools that the German experience of the war received relatively little attention, and they were keen to expand understanding. The project grew out of COTGW, which had advertised collection days in five locations around London and invited the descendants of First World War survivors to bring in objects from the war and share the family stories associated with them. The idea had developed from witnessing one of the collection days of Europeana I9I4-I9I8 (part of the Europeana Collection, a project co-funded by the European Union that digitalizes historical artifacts and papers) during which objects passed down through the generations within families were photographed for inclusion in its online archive. ${ }^{10}$ It was evident that the medals, letters, cards, and photos came freighted with stories that were just as significant to the descendants as the objects themselves, stories that for many took them back to their own childhoods to the time when they had first encountered these family legacies. ${ }^{11}$ AE designed COTGW as

8 Schweitzer, "Making Memories," 84

9 Ibid., 90.

Io Europeana I9I4-I9I8, Untold Stories and Official Histories of WWI, https://pro.europeana. eu/project/europeanargi4-I9I8.

II An Australian interviewee explained that he connected to the past through family objects; as he stated, "they give you a grounding in where you come from; if you don't know where you've come from you don't know where you're going." Quoted in Paul Ashton and Paula Hamilton, 
a project that could expand on Europeana's basic collection mechanism in order to capture the memories of these children and grandchildren as a way of exploring the war's legacies in domestic life. The day-long collection events were organized with a team of volunteers doing interviews of between half an hour to an hour with technicians on hand to produce high-resolution digital images of the family objects. That work had drawn AE towards the descendants and the memories of the conflict passed down from the war generation to the second and third generations. The stories collected for COTGW were captured in an hour-long testimony film and a theater production in which local schoolchildren played a role in the dramatization of the elders' memories. The international dimension of the new project made the pupils' direct involvement impossible, but it was intended that the filmed material and related MINML apps would be used to engage with younger audiences and develop their understanding of the legacies of the conflict.

MINML was more explicit than the COTGW project in focusing on family legacies among successor generations, the aim being to "explore how the war affected those families from the inter-war [period] through to participants' experience of remembrance and commemoration today." 12 It drew on the COTGW approach, using objects as the centerpiece around which people's stories of the war could emerge. There were, however, important differences. Whereas COTGW was essentially an individual experience for the participants-they came in, did an interview, had their artifacts digitized, and met other participants over a cup of tea or coffee-MINML was envisaged from the start as a collective process. Participants would begin by doing individual interviews, as they had in COTGW, but would then be brought together as a group through activities including art, performance, meals together, and local visits, so that the histories of individuals could be viewed together both between and across nations. In this, David Savill, AE's artistic director, drew on the performative aspects of AE's approach to reminiscence. The focus for the film then became the documenting of how people were brought together and what had emerged from the exchange of their stories, rather than the approach of documenting individual stories as AE's film Children of the Great War had done.

\section{Planning in Rosenheim}

MINML was four years in the making, but detailed planning began in early 2015 with a day-long workshop involving David Savill, Essex University, and two German organizations involved in elder care, one a Catholic charity called Caritas based in Rosenheim, near the Austrian border, and the Münchner Bildungswerke, Programme Die Lange Schatten des Krieges based in Munich. Our partners were from mixed backgrounds, the Rosenheim group being mostly made up of social workers, whereas the Munich group included care professionals as well as

"Connecting with History: Australians and Their Pasts," in People and Their Pasts: Public History Today, ed. Paul Ashton and Hilda Kean (Basingstoke, UK: Palgrave Macmillan, 2009), 3I.

I2 Age Exchange, HLF Bid, 20I5. 


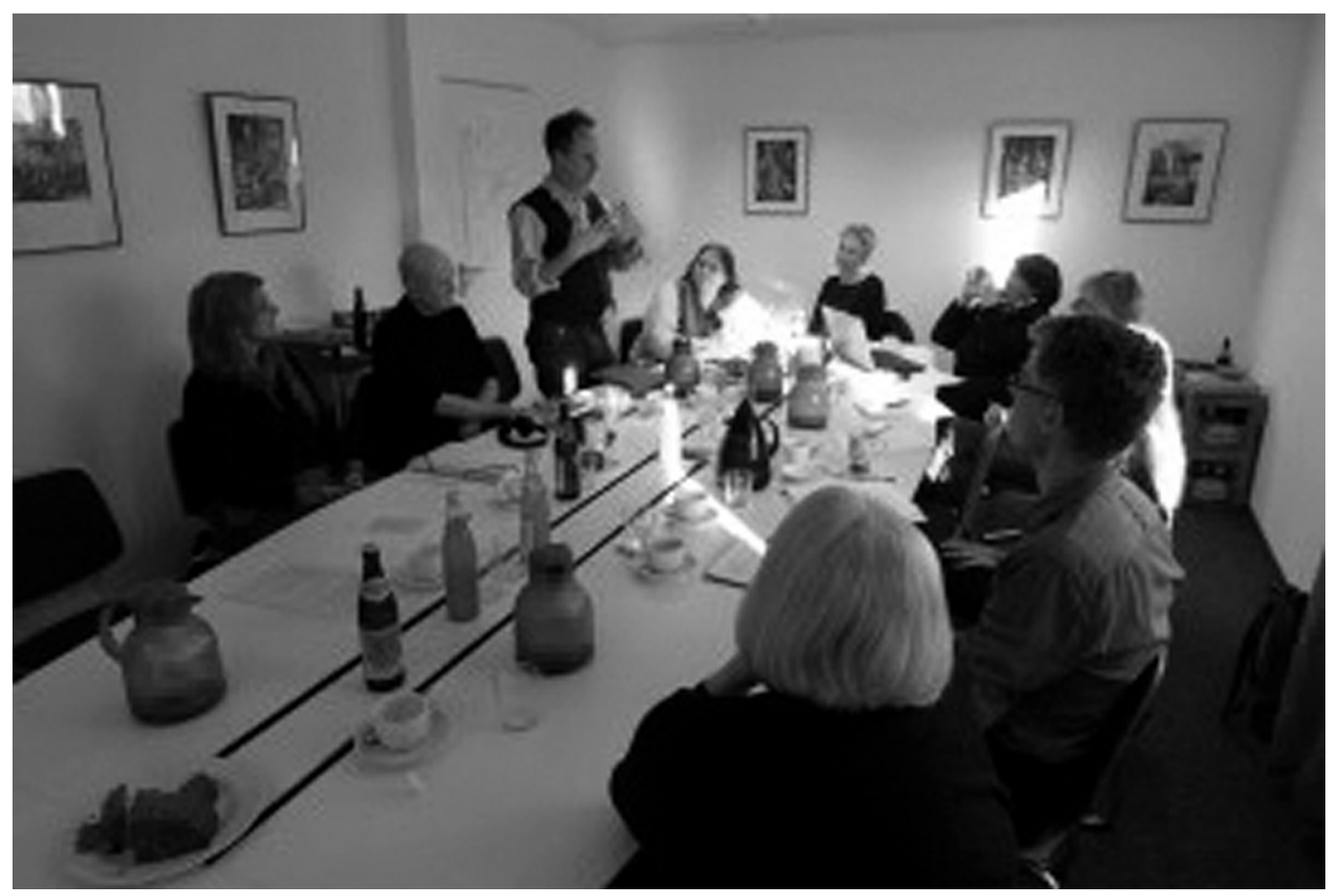

David Savill, Artistic Director of AE at the January planning meeting in Rosenheim. (Image courtesy of Age Exchange)

a psychologist living in Dachau who came to the project from therapeutic work with the German children of the Second World War generation, including National Socialist supporters. Funding was secured from the HLF in late 2015, and a meeting took place in mid-January 2016 to plan the details. During this, the participants were encouraged to bring in their own war artifacts and tell their own family stories, and this became a means of bringing the team together and of developing the approach to MINML. It was here that the differences between oral history and reminiscence therapy practice began to emerge. The level of personal involvement in the process from those organizing the MINML project was different from that which would be usual for the oral historian. Both David Savill and Jürgen MüllerHohagen, the psychologist from the Dachau Institute, are descendants of First World War veterans; their engagement was not purely on an organizational level as they also had a personal investment in the meeting.

As academics observing the process, what was also apparent was the great difference between the MINML and the scope of a research project. The event was logistically ambitious: elderly people had to be transported safely from the United Kingdom to the Austrian border, and accommodations, as well as appropriate venues for interviewing and filming, had to be found. There were complicated decisions about how to handle the interviews, such as how to deal with language differences and whether native speakers would conduct interviews or if 
the project would use translators. The time-consuming and complex arrangements seemed a long way from conducting historical research through individual interviews without the additional issues of simultaneously managing a residential, bilingual group process. The challenges meant that both British and German organizers had to work very hard together to find solutions, and they rapidly forged strong relationships. Intimacy developed quickly, in part due to the sharing of experiences at the initial planning session, but also as a result of the organizational pressures of the project. The care and concern that was reflected in AE and its partners' efforts to organize the travel and accommodation arrangements was also present in the welcome that we were given by our Bavarian hosts. The German budget for the project was minimal-no HLF there-and so the planning meeting had been pulled together through both the good will of Caritas, which donated the meeting space, and the endeavors of individual participants. When we sat down to our delicious lunch it became apparent that it was the product of local initiative-the hosts had each shopped, chopped, or baked in order to produce the meal for us, their guests. Food is a powerful means of communication, and sharing those homemade dishes, prepared with care and testimony to the personal commitment of their makers, was a significant moment. These were people who did not require funding to generate activity, and unlike many self-funded groups their focus and investment was not turned in on themselves, it was directed outwards, and that generosity of spirit pervaded the project. The warmth of the German reception drew attention to the geographies of the project's title: we weren't actually meeting in the neutral no man's land, we were being welcomed in deepest Bavaria, far behind the frontline of a century before. The journey by the British descendants into (former) enemy territory would bring the war home to the heart of Germany, a disruption of the original battle lines that had kept the combatants apart from this nation, further evidence of the uniqueness of AE's project.

\section{Selecting and Interviewing British Participants}

Back in Britain, the twelve British participants were interviewed by AE in late March. Most of them had previous connections with AE. In contrast to a more typical research process, which usually aspires to seek out unknown populations, these participants had been chosen on the basis of known stories, many through previous involvement in COTGW, and on their capacity to work within the group. When the importance of the latter became evident during the selection process, it felt strange to us. It is not a consideration when selecting oral history subjects who do not usually participate in a collective process. The initial experience at the planning meeting had its impact, however, and it was becoming apparent to us that synergy was going to be a significant factor in the success of the project. The reminiscence-theater work model relies on the building of a company that to a degree is focused on the final performance, but also relies on the ability of that group of people to work together effectively. In the same way that a theatrical 
director recruiting a company looks not just for ability but also for congeniality and a willingness to share experiences and work with others, so AE built its British MINML group. Some historians might balk at this criterion, given that we are often most interested in the outliers, the sources that don't quite fit the established model. The creative processes were different here as well. Writing history is usually done with the luxury of temporal distance from the research, but MINML's collection and production stages overlapped; the connections between different narratives would start to be developed in real time by the subjects themselves in front of the cameras. The requirement of ensuring that the MINML environment was one in which these processes could work required an additional set of considerations. David and his team knew that the sharing of intensely personal memories in such a format could only be achieved if the participants were happy to work with and trusted each other. The selection criteria meant that most of the British participants were to an extent habituated to AE's way of working. In the individual interviews, they recounted familiar narratives and the process of filming further contributed to the "fixing" process, as participants went over parts of their story again while the camera took close-ups of them with the objects they had brought.

\section{The German Contributors}

The meeting itself took place over four days in early April. All twelve German participants were interviewed on the first day, necessitating a tight timetable with two teams of interviewers and a translator. Unlike in the United Kingdom, there did not appear to have been a selection process. The number of people with an interest in the war and a family story of some kind that they wished to share was limited, making all those who had volunteered participants. In part, the material that people brought was familiar: letters, postcards and diaries, photographs of parents and grandparents, objects crafted during the war, and military memorabilia such as medals and swords. Holding these heirlooms and explaining their significance aroused the same kinds of emotions, of loss and of pity, knowing what ancestors had lived through. But we also began to get a sense of the differences between the British and German participants, most notably, in Germany, the lack of knowledge about ancestors and the recent attempts to find out more, the lack of a commemorative framework within which to place the story, and the burying of the first war under the rubble of the second. Germany's role in the Second World War made it difficult to see the first separately, and it was clear that the wars had impacted families in Germany in quite complex and sometimes fraught ways. There were stories of family friction between interviewees and their parents who had blamed the peace settlement for Germany's situation in the Second World War, as well as descriptions of mistreatment by the Allies in the post-I945 denazification process. For the most part, however, the emotional tone was one of solemn contemplation, as the German descendants talked about the war's impact on their family, many of 


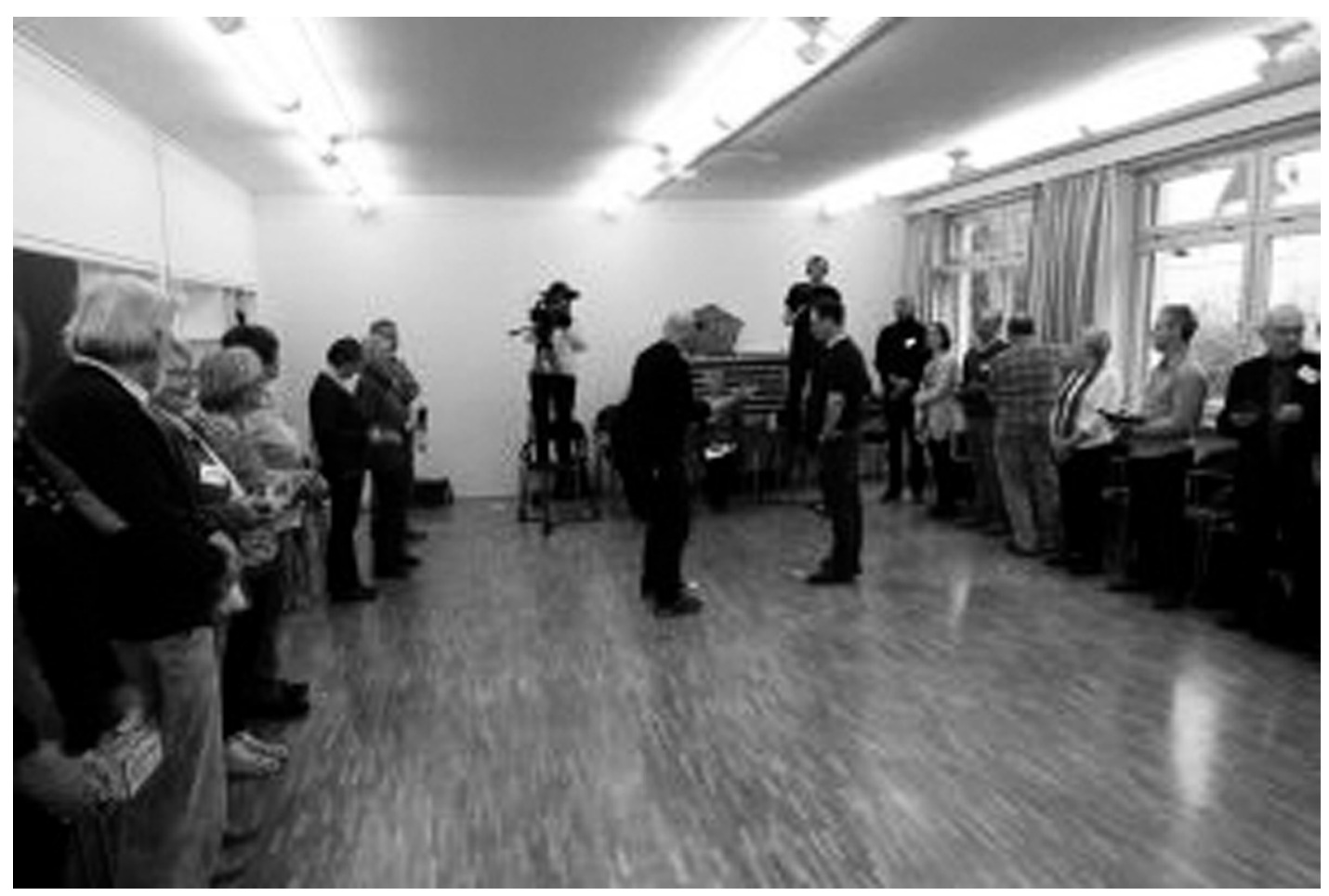

First day of filming British and German descendants in Caritas, Rosenheim, April 2016. (Image courtesy of Age Exchange)

them remarking that this was the first occasion on which they had spoken about such things.

Towards the end of the interviews, one of the interpreters, an American living near Rosenheim, broke down in tears, expressing feelings we all shared (and which the participants had held throughout their lives) about the hardships undergone by parents and grandparents in the two wars. Additionally, the German interviewees had not been acculturated to AE's ways of working and they lacked the familiarity with recounting their stories that most of their British peers had developed from earlier engagement with the organization. For them, speaking in front of cameras and describing difficult memories to interviewers they had never met before no doubt presented an additional set of challenges. Although the Bavarian contributors did not have the reminiscence experience of the British visitors, any lack of practiced fluency in their accounts was more than compensated for by the enthusiasm with which the relative uniqueness of their stories was greeted. The lack of integration of German family stories into a clearly defined national narrative of the First World War emphasized their emotional power and seemed to enhance their significance in the context of the event, facilitating the integration of these participants into the AE process. Hospitality was also important in the rapid melding of the group; the local interviewees made great efforts to welcome the British 


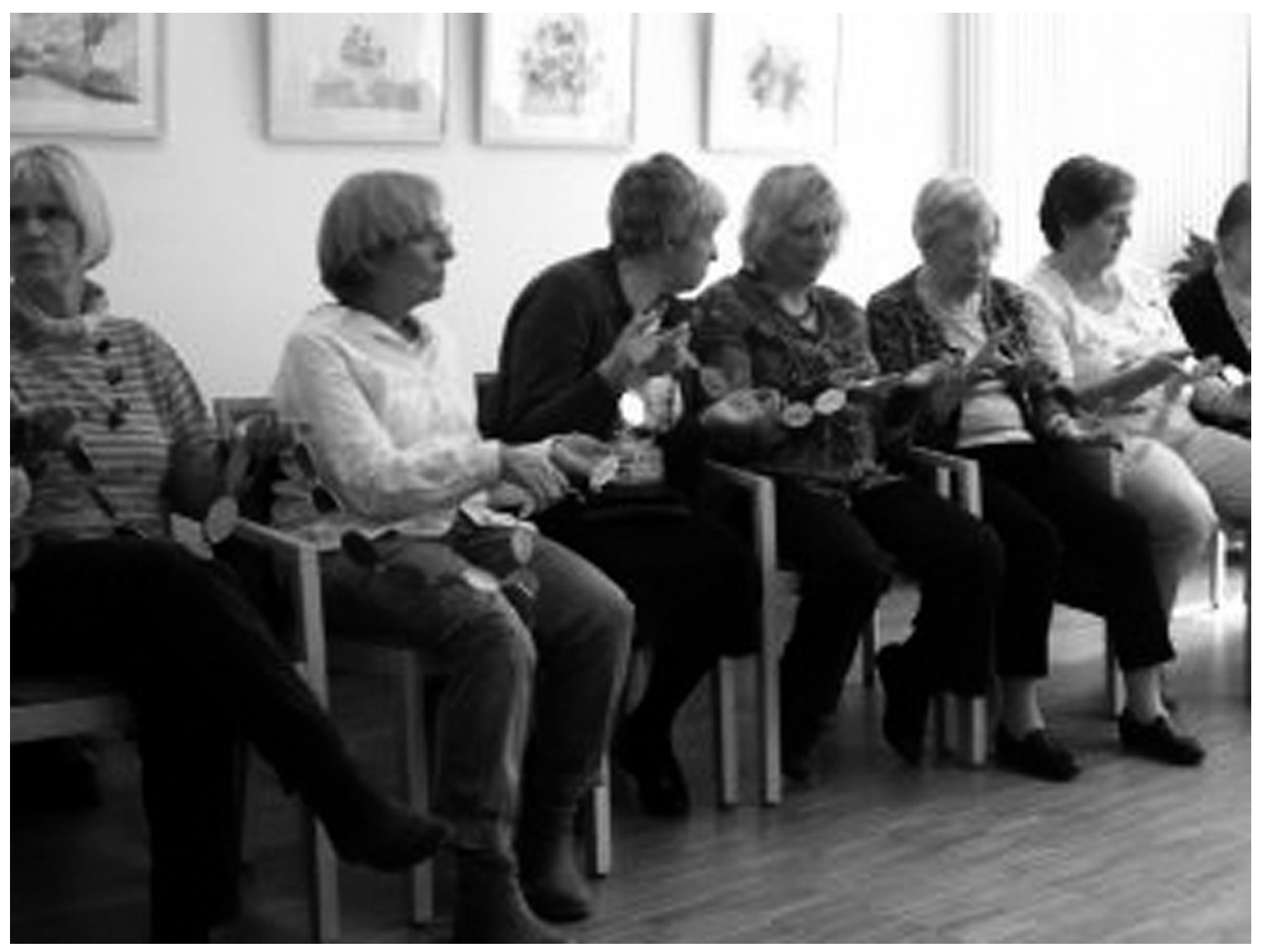

British and German descendants hold the chain they have made linking re-creations of the dog tags of fathers and grandfathers who fought. (Image courtesy of Age Exchange)

visitors, and the warmth of their reception-including the offering of the local schnapps-helped to draw the participants together.

\section{Commemoration in Two Nations}

The following day, we visited the Rosenheim war memorial, and it quickly became clear that, in contrast to monuments in Britain, this was not a site that local participants tended to visit. The differences between the national narratives of commemoration were apparent and the confusion over the location and meaning of the monument reflected the long and troubled history of mourning the First World War's dead in Germany. Later, Jürgen and Mike (essay co-author) presented to the group on the different national contexts of remembrance, and the British investment in memorialization, both cultural and economic, was a striking contrast to the war's absence in German society. Indeed, this lack of information proved to be a motivating factor for some of the Bavarian interviewees, who were drawn to the process by the desire to understand the (inter)national events that had shaped their families but of which they had little knowledge. A number of them said that beyond the dates, they knew nothing because the subject was not taught in schools 
and there were limited traces of it in German popular culture. Their immersion in the "culture of remembrance" that has expanded in Germany in recent decades had been mainly confined to post-I933 events and the social and cultural impact of the First World War remained hidden. ${ }^{13}$

Involvement in MINML had spurred several participants to actively seek out information on the First World War, both in general historical terms (two had recently read Christopher Clark's Sleepwalkers) and within their own family, leading some to discover objects related to the conflict that had lain hidden for a century. ${ }^{14}$ For others, objects had not been hidden away, but that did not mean that their stories were known. For example, no one knew the provenance the French bayonet that a grandfather had brought back from the Western Front and had been displayed on the family's wall for years, and there was nothing in the participant's experience that had provided a framework within which the possibilities of its origins and history-and therefore the grandfather's-might be explored and understood. By contrast, the British participants were mines of information on the conflict, as a very different national experience ensured that detailed knowledge of the war was never in short supply. ${ }^{15}$

\section{First Meeting in No Man's Land}

The two sets of participants were brought together for the first time on Saturday, April 9. They joined in a general discussion about the importance of the war and its legacies before the symbolic centerpiece of the event, the meeting, commenced. Based on the idea of the Christmas truces of I9I4 and I9I5, when German and British troops met and exchanged greetings in no man's land, the two sides lined up on opposite sides of the room and advanced to face each other, introduce their family artifact, and exchange stories about it. This began the process of familiarizing, whereby participants were drawn through reminiscence into a fictive family. ${ }^{16}$ It was one of the most challenging moments of the whole project because the participants were being asked to engage with a person unknown to them and explain their family history and object on camera. The technicalities of visual performance are more complex and more inhibiting than those associated with a single interviewer and a sound recorder. It was hard to ignore the mechanics of cultural

I3 See, for example, Alon Confino, Germany as a Culture of Remembrance: Promises and Limits of Writing History (Chapel Hill: University of North Carolina Press, 2006); Maja Zehfuss, Wounds of Memory: The Politics of War in Germany (Cambridge: Cambridge University Press, 20II); and Jenny Wüstenberg, Civil Society and Memory in Post-War Germany (Cambridge: Cambridge University Press, 20I7). A fuller discussion of national and family commemoration of the First World War in the context of MINML can be found in Roper and Duffett,"Family Legacies in the Centenary."

I4 Christopher Clark, The Sleepwalkers: How Europe Went to War in 1914 (London: Penguin, 2013).

I5 See Roper and Duffett, "Family Legacies in the Centenary," which explores the similarities and differences between family legacies among the British and German participants.

I6 Jay Winter, "Forms of Kinship and Remembrance in the Aftermath of the Great War," in War and Remembrance in the Twentieth Century, ed. Jay Winter and Emmanuel Sivan (Cambridge: Cambridge University Press 2009), 40. 
reproduction, and for many there was a self-consciousness that came from all the requirements they had to bear in mind: stand up and speak in front of an audience you barely know; talk clearly and not too fast; hold the object so the camera can see it; look at the object; look at your partner; don't look at the camera; and forge a meaningful connection with someone you barely know and whose language you cannot speak. It was hard, and AE's selection processes proved their worth as the grace and courage demonstrated by all was impressive. It took a certain type of person to accept this challenge as the performative aspect, also present in oral history interviews, was much magnified here, and the participants literally were actors on a stage with a reasonably large audience. What made the process work was the presence of a skilled and empathetic director. David's knowledge of performance and expertise in both reminiscence therapy and oral history combined with his natural sensitivity to ensure the successful management of a technically and emotionally demanding situation that, in the wrong hands, had the potential to go horribly wrong. The speakers were also sustained by the attentiveness of their audience, who joined in an act of listening with remarkable intensity. The newly formed group had created connections and began to develop its collective power, willing the pairs to succeed in their task and generating almost tangible threads of support and encouragement in which the speakers found themselves suspended. Everyone in the room felt the responsibilities of their role and all were fully engaged in a way that we have rarely witnessed. "Experienced" would perhaps be more accurate as it was difficult not to be caught up in the emotional intensity of the event, and "observing" would have required a conscious distance, which was hard to maintain when relentlessly pulled in by a process that demanded close engagement.

\section{Sharing in Pairs}

The next day, the twelve German and British participants paired off and interviewed each other, most via a translator, with a few brave descendants conducting the interview in the language of their counterpart. In some cases, it proved difficult to make a connection. Communication through an interpreter, however sensitive to the situation, is never easy and conversations were fractured by the inbuilt time delay between delivery and response. Whatever the problems, the participants shared the desire to overcome them, and their concentrated listening that was by necessity part of the interaction facilitated the building of further connections between the pairs and they were able to find common ground. Angelika and Chris shared stories of their grandfathers' bravery. Chris's had held up a disintegrating bridge on his own shoulders in order that his fellow soldiers might cross. Angelika's grandfather had never discussed the war with his family, but he was a teacher much respected for his enthusiasm and courage, which led to him frequently being called upon to deal with the most difficult and aggressive classes, something she felt was a product of his years as a soldier. Hanne and Hilary talked about the conflict's legacy of trauma in their respective families: the grandfather who had no emotion 


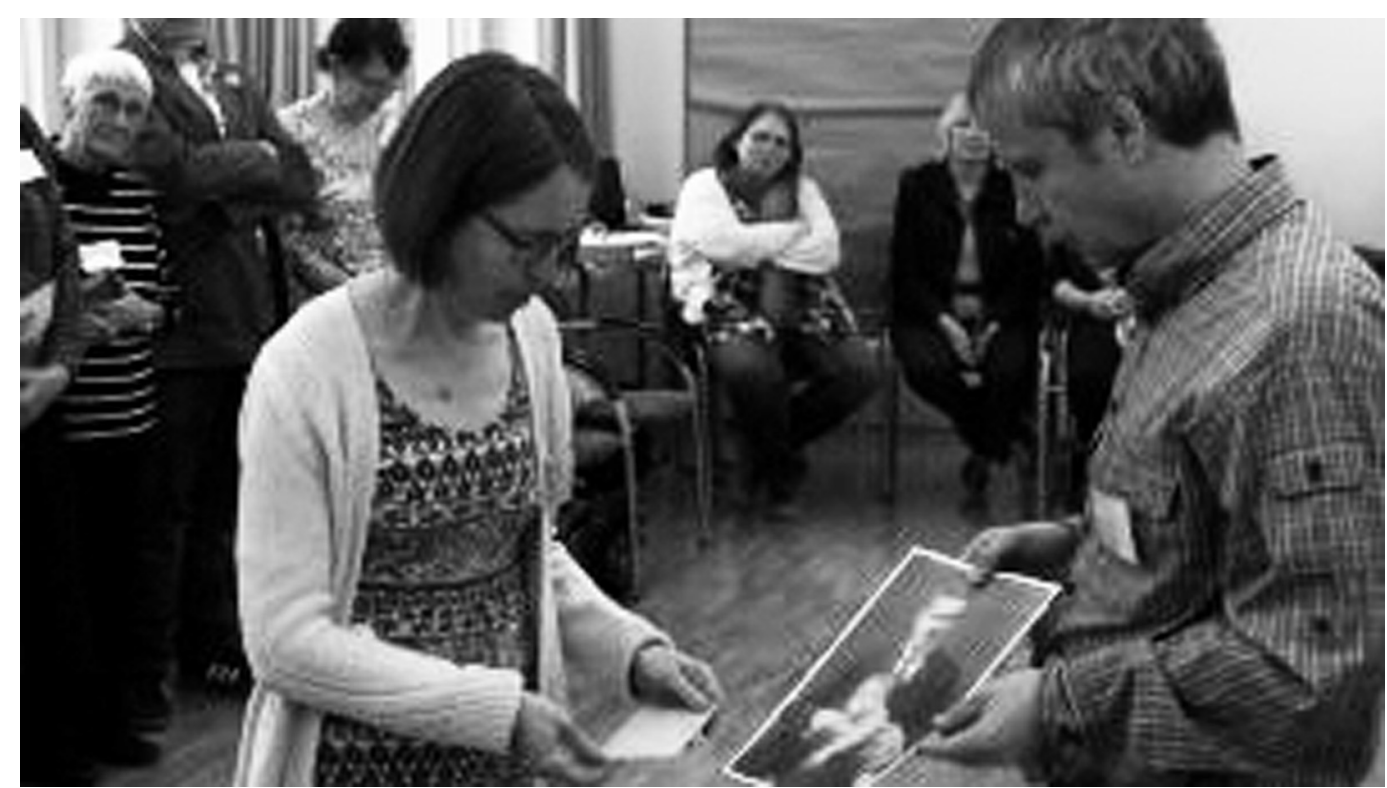

Participants Hilary and Dieter exchange their family histories from the First World War. (Image courtesy of Age Exchange)

for his family, whose enthusiasm for orderliness in life had made him an early recruit to the Sturmabteilung (storm troopers), and the grandmother who, with her sisters, had been consigned to the workhouse at six years old when her father's death in action left his widow incapacitated by the shock. And then there was the pair with which this account began, Ruth and Linde. The desire for peaceful European unity had been a sentiment much expressed on the previous day at the initial group meeting when many pointed to it as their reason for participating in MINML-a principle that is particularly salutary in the post-Brexit world. Ideas of peace and understanding are fine, but it is hard to embody political and philosophical truths. Ruth and Linde achieved that embodiment. They had lived with fathers damaged by the conflict and mothers whose lives had been circumscribed by their husbands' military service, they had both endured the second war, and now here they were joined together in no man's land.

\section{Reminiscence Work and Oral History}

MINML was an immensely moving project for its onlookers as well as its organizers and participants, and it raised questions for us as historian observers about the way in which AE worked. Oral history and reminiscence work now occupy similar territory, a terrain explored by Joanna Bornat who has examined the commonalities as well as the perceived differences. ${ }^{17}$ Bornat writes that, observed

I7 Joanna Bornat, "Reminiscence and Oral History: Parallel Universes or Shared Endeavour?" Ageing and Society 2I, no. 2 (March 200I): 220. 
from the outside, it might be hard to distinguish between the two, but that "things feel quite different when viewed from the inside." 18 For Bornat, the key difference seems to be that reminiscence activity gives additional attention to the process itself and to the outcomes for its participants. She notes that an additional objective of reminiscence is the sharing of the memories collected "with a view to understanding each other or a shared situation or with the aim of bringing about change in their [the participants'] current lives."19 Bornat emphasizes a different relationship between the oral historian and interviewees and a reminiscence practitioner and participants, based on the reminiscence practitioner's perceived greater subjective engagement with the process and additional motivation to empower or deliver a therapeutic experience to contributors. It is a definition that feels somewhat distinct from the current practice of oral history, given the emphasis Bornat gives to a perceived separation between the oral historian and interviewees and the emphasis she places on the uncovering of lost histories. The notion of oral history's prime motivation being the mining of untapped seams of social history is a long way from current understandings, in which focus on the relationships and the subjectivities between interviewer and interviewee is fundamental.

MINML diverged from usual forms of oral history in that it situated the individual and paired interviews within a collective process that linked participants, organizers, and observers. Group interviews while not unheard of in oral histories are unusual and often a reflection of cultural practices rather than part of a fundamental strategy for the project. ${ }^{20}$ It is hard to be categorical about the impact of telling one's story in a group rather than to a lone oral historian, depending as it does upon individual reactions to different situations. For some, group work can have a disinhibiting effect and encourage participation because it is easier to bear than the focus of a single spotlight, but for others, the intimacy of an individual meeting with a trusted interviewer will elicit a richer response. The ability of the whole MINML group to listen in an unusually intense fashion was significant-this was active listening as hard labor. People were sharing similar stories of family legacies and they all carried a profound belief in the importance of what they were doing and how they were doing it. The potential power of listening is a key aspect of working in groups as it coheres the group and facilitates deeper emotional connections. ${ }^{21}$ Schweitzer has written about the special quality of listening that can be developed in some reminiscence relationships, and the MINML group

I8 Ibid., 219.

I9 Ibid., 223.

20 For example, where it would be culturally inappropriate to interview women individually, see Hugo Slim et al., Listening for a Change: Oral Testimony and Community Development (London: New Society Publishers, 1993).

2I See, for example, Coleman, "Reminiscence within the Study of Ageing," I7, and Mike Bender, "An Interesting Confusion: What Can We Do with Reminiscence Group Work?," in Bornat, Reminiscence Reviewed, 32-45. 
rapidly achieved a level of intimacy through a strong sense of being heard, supported, and, to a great degree, understood by their fellow members. ${ }^{22}$

It became evident that AE's relationships often extended beyond the limits of the actual project activities themselves. Following the sharing of their memories during the COTGW project, a number of participants had formed close ties with the organization, becoming part of its extended family, and their continued wellbeing was matter of concern for AE. The nature of these ongoing relationships differs from those formed by oral historians, even those who may reinterview the same subjects after a period of time as part of an ongoing research project, as AE's involvement is deeper and more personal. Alastair Thomson has noted the ethical dilemmas oral historians face when a "therapeutic relationship" emerges in their contact with interviewees because, unlike therapists, they "would not be around to help put together the pieces of memories which were no longer safe." 23 AE had remained present in the lives of many of the British contributors and their participation in the earlier project, the COTGW, had been fundamental for the development of the idea for MINML. It is, perhaps, this kind of continuing relationship of which Bornat was thinking when she wrote of the greater interest in the outcomes for participants as differentiating reminiscence work from oral history. AE's involvement sometimes extended beyond the individual contributor to include other family members in the MINML group, for example when an elderly participant needed the additional support of an accompanying (adult) child, or through the continued contact with the family of a COTGW interviewee who had recently died.

\section{Performance and Power}

One fundamental difference Bornat identified in her comparison between the practices is the performative aspect of reminiscence work, something key to AE's activities in the community where theatrical performances were integral to earlier projects. Bornat described organizing a reminiscence performance titled "The Good Companions" at an academic conference and her concern that academic historians might disregard the performance. In fact, the program was received rapturously and she noted that the audience's emotional responses "belied the objectivity and detachment of their own highly professionalised reputations."24 There is a performative aspect to oral history as well: every interviewee has some kind of imagined audience in mind, and it is the desire to find a destination for their stories that motivates individuals' engagement with the process. Our understanding of oral history interviews is founded on the acceptance that how a story is told is as important as what is said, form is as significant as content, and the way in which the

22 Pam Schweitzer, "Dramatizing Reminiscences," in Bornat, Reminiscence Reviewed, 106.

23 Alastair Thomson, "Anzac Memories: Putting Popular Memory Theory into Practice in Australia," in Perks and Thomson, Oral History Reader, 302.

24 Bornat, "Reminiscence and Oral History," 230. 
narratives are narrated/performed is central. In addition, the theatrical element is no longer exclusive to reminiscence work, and the performance of oral histories is an accepted outcome, taking many forms from historical reenactments and heritage events to drama. ${ }^{25}$ The 1987 staging of the Flint Labor History Project's work on the 1936-37 Flint sit-down strike, for example, was an effort to "reacquaint them [community members] with their own history and their own class's accomplishments in the building of a once proud city." ${ }^{26}$ The project was founded on the belief that the presentation of a community's history to its descendants would allow the past to empower the present. Unlike the Flint project, with its use of professional actors, reminiscence performances are usually enacted by the subjects themselves, which does give them a more specific therapeutic function.

Bormat argues that the performance process of reminiscence projects is important because the participants are in equal partnership with those collecting the memories, and this allows them to retain control over their contributions. She regards this as a significant difference between the two disciplines, because in oral history the subsequent interpretive role lies in the hands of historians, thus determining their supremacy in the power relationship. ${ }^{27}$ Bornat identifies the way in which the life stories are shaped by their tellers in the process of creating a reminiscence performance piece and argues that the participants' consent to the way in which their memories are used is implicit in their acts of co-creation and performance. This is especially significant when the subject matter is painful, and the prospect of reenacting traumatic life events might be problematic for the participant. The process of working with the company and the support and the sharing of each other's life stories enables individuals to enact problematic pasts in a way that helps them to come to terms with emotional pain. ${ }^{28}$ This empowerment of the subject was a possibility originally developed by UK reminiscence practitioners from their experience of oral history work. They recognized that oral history techniques could be adapted to collect the stories of the elderly, who were largely unheard in society, and that the process would empower the tellers. This realization led to the government's funding of the Reminiscence Aids Project in $1978-79 .{ }^{29}$ In the writing of history, empowerment has its limitations, and while some oral historians may allow subjects to review the transcripts of individual interviews, the shaping of the final output and the ownership of it lies with the researcher. The interviewees are generally separate from the processes of analysis and reflection from which meanings are drawn and history is written and their contributions are only one part of a broader context. ${ }^{30}$ Processes of analysis are generally not part of

25 Abrams, Oral History Theory, I30 and 139.

26 Shaun Nethercott and Neil Leighton, "Out of the Archives and onto the Stage," in Perks and Thomson, Oral History Reader, $45^{8}$.

27 Bornat, "Reminiscence and Oral History," 232.

28 Ibid., 229.

29 Abrams, Oral History Theory, 158-59.

30 Jan Walmsley, "Life History Interviews with People with Learning disabilities," in Perks and Thomson, Oral History Reader, 136. 
oral history outputs and it seemed that the MINML project, partially because the end product would be a film instead of a play, had more in common with the unmediated "memory books" in the Studs Terkel tradition. ${ }^{31}$

\section{A Film Rather Than a Play}

The role of reminiscence participants as integral to the output created is less straightforward when, as in the case of MINML, the end result is not a theatrical performance but a film. The processes of filmmaking differ from those in the theater and the subjects' engagement with its creative processes is more limited. The pressures on the participants to contribute strong performances from the very start were great, and unlike in a play, there would be no opportunities to repeat and hone their contributions. Primarily this was because the film was to be a documentary that captured the spontaneity of responses and interactions, but also because there were insufficient funds-and time-for retakes. Once their contributions had been filmed, the participants' involvement in the final format of the film ended. Decisions of inclusion and exclusion would be made by the film's director and creative team from the hours of raw material collected; the partnership aspect of creating a live performance in which the contributors are actively involved was absent. In some ways, the postproduction phase of filmmaking brings it closer to the processes historians apply to their research, but there was a significant difference in initial approach. At the outset, filmmakers need to have, if not a script, at least some kind of artistic vision of the final product, whereas in historical writing the outcomes tend to emerge as a result of the research. The vision of what the film should be was present during the progress of the project and informed which of the narratives were encouraged and the way in which visuals were captured. AE's approach was shaped both by its artistic aspirations and by the funding process, which required the detailed specification of the project's outputs and timescales prior to its inception. Although this would seem to distinguish filmmaking from academic writing, such criteria are becoming increasingly pressing for the historian, and the era of a fully open-ended approach to research projects has all but passed.

The act of creating narratives, whether for theater, cinema, or the page, requires curating processes; all audiences need to be offered a pathway into the unformed mass of data. A consideration for us observing MINML was the extent to which this activity might reduce the original complexity and diversity of the participants' stories. Madge Dresser has noted the pressures for public history to be celebratory, to avoid controversy by ensuring that it "censors offensive descriptions, [and] glosses over difficult issues." ${ }^{2}$ Similarly, reminiscence theater seeks to mediate traumatic memory through the rehearsal process; the creation of the performance

3I Michael Frisch, "Oral History and Hard Times: A Review Essay," in Perks and Thomson, Oral History Reader, 3.

32 Madge Dresser, "Politics, Populism, and Professionalism: Reflections on the Role of the Academic Historian in the Production of Public History," The Public Historian 32, no. 3 (Summer 2oro): 58. 


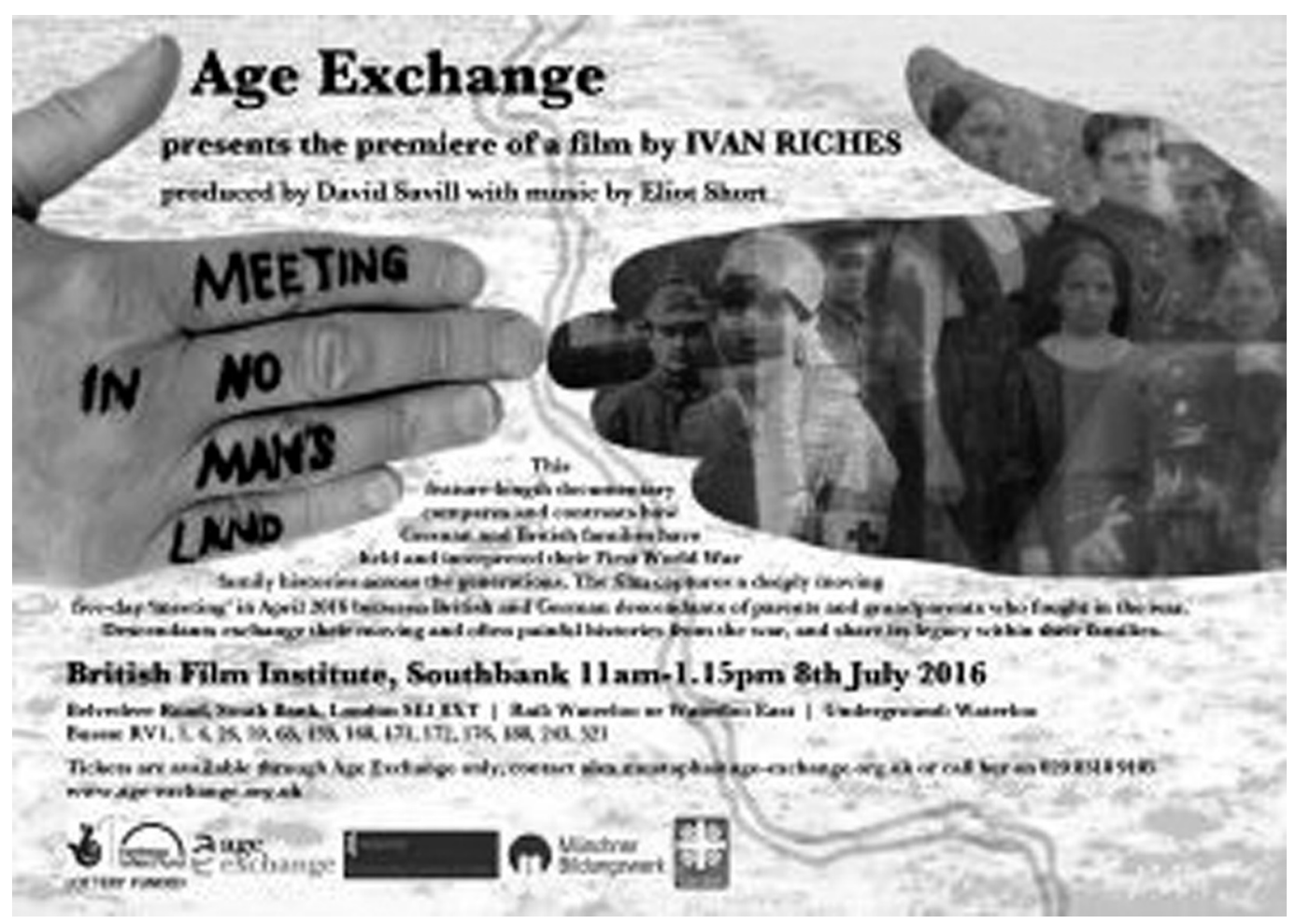

The premiere of Meeting in No Man's Land at the British Film Institute, London Southbank. (Image courtesy of Age Exchange)

necessitates its resolution into a stable form that is tolerable to the actor and also the audience. Bornat highlights the repetitions required to generate theatrical output, how it is through those iterations that the performance is created, and how the individual players achieve an emotional composure through the process. The situation was similar for the British MINML participants. Their stories had been told and heard several times and the process had formed them into self-scripted narratives that varied little from one telling to another. The composition of memories into a narrative of the past with which the individual is comfortable often occurs in an oral history interview. ${ }^{33}$ However, one difference between the approaches of a historian and a reminiscence practitioner is the former's desire to explore the narratives within their wider historical context. Individual memories are analyzed within a framework of broader influences and understandings, a context that allows for an analysis of the facts recounted. Historians acknowledge the fluidity of their sources and their ability to be shaped by personal subjectivities and public narratives, but this was not part of the MINML process. The stories collected were accepted uncritically, and there was no opportunity to consider why they

33 See Alastair Thomson, "Introduction," in Anzac Memories: Living with the Legend (Melbourne: Oxford University Press, 1994). 
might have taken particular forms. The focus instead was on how they might be incorporated into the overall vision for the outputs.

\section{Commemorating Loss in the Centenary}

The centenary of the First World War has meant not only a proliferation of events marking the losses of I9I4-I8 but also a corresponding growth in the efforts to understand what those events mean. Over the past few decades, historians have given greater attention to organizations and activities in which enthusiasts have joined together to commemorate the war, for example the popular First World War reenactments in Britain. The performing of the military past at events and festivals has been a way that individual interests, often springing from a family legacy of the conflict, could be explored in a group setting. ${ }^{34}$ The British national narratives, and the public with whom they resonate, have been much critiqued for their adherence to the dominant myths that have grown up around the conflict, appearing to revel in the mud, blood, and suffering. Other historians have pointed out that such a position ignores the continuing power of the war to stimulate intense affective responses in the public. ${ }^{35}$ It could be argued that the potent atmosphere created by the centenary, fueled by media activity and the British government's spending, has served to create a "community of feeling." Berezin defines this as a place where the nation, or significant parts of it, is brought together in a series of defined spaces "for a discrete time period to express emotional energy." ${ }^{36}$ In MINML, AE had recognized the way in which the feelings surrounding the commemoration reached into individual British families. The project connected with a desire to articulate the deeply embedded memories and events originating from the war that had been passed down through generations. MINML differed from other semi-personal commemorative activities, such as the reenactments, because while the latter may use family experiences to inform a public engagement with the war, the emphasis is on looking out from their personal legacies to the national, usually military, narratives. None of the contributors to MINML had any desire to involve themselves in such public re-creations of the past. Instead, the direction of influence was reversed and they sought information on events external to their families in order to try and understand those private domestic interiors more clearly.

The experiences of the veterans formed the core of these MINML contributions, but the years of retelling meant that they had become family narratives that reflected the repeated iterations and paid testimony to scripted roles within those families. When they were recounted for MINML, the contributors were

34 See Vanessa Agnew, "History's Affective Turn: Historical Re-enactment and Its Work in the Present," Rethinking History: The Journal of Theory and Practice II, no. 3 (2007): 300-30I.

35 See, for example, Michael Roper, "Subjectivities in the Aftermath: Children of Disabled Soldiers after the Great War," in Psychological Trauma and the Legacies of the First World War, ed. J. Crouthamel and P. Leese (Basingstoke, Palgrave, 2016).

36 Mabel Berezin, "Secure States: Towards a Political Sociology of Emotion," Sociological Review 5o, no. 52 (October 2002): 39 . 
performing not only their ancestors' memories, but also their own role as those with the responsibility of carrying the fragments of these lives into the future. For the British contributors, these were almost exclusively highly emotional accounts enacted within the charged arena of the centenary, and the responses that they generated in all were intense. Prior to MIMNL, the tears shed on television by the subjects of the popular genealogy program Who Do You Think You Are over the lives of men and women unknown to them and dead for centuries might have appeared puzzling to us, but post-MINML that perspective shifted. Anna Clark has described the emotive power of acts of commemoration, which comes not so much from the events commemorated, but from the way in which the collective grief acts as a conductor for our own personal losses. ${ }^{37}$ During MINML, the group functioned as a micro community of feeling, and the heightened emotions in the individual stories resonated powerfully with the onlookers/listeners.

It was in the group process that the difference between MINML and oral history was keenly felt, primarily because of the way in which its collective nature presented difficulties in maintaining the distance fundamental to historical understanding. This emotional telescoping was reinforced by the elision of the usual stages of producing a historical narrative, by the way in which the film output was being constructed as the participants spoke. The "specialized form of human insight" that is history requires a distance between the material and its interpreter. ${ }^{38}$ MINML organizers were wholly attuned to the emotional register of the process, but standing back and analyzing those emotions was not part of the project. Instead it was about capturing them on camera: execution not analysis. The MINML film is fascinating and moving, but it is not an interrogation of the events or of the family legacies that fed into the project; rather, it is a documentary record of them. ${ }^{39}$ The emotions discharged during the process raised further questions for us about the nature of the war's commemorations and the attraction it exerts. Mark Salber Phillips has argued for the acknowledgement of the "structures of feeling" in writing history, of how a pejorative definition of sentimentalism as excessive emotionalism rejects the possibilities inherent in an approach that takes those feelings more seriously. ${ }^{40}$ MINML was an outstanding example of how individual family stories and their associated emotions have a life of their own, one that is not wholly symbiotic with the national narratives and one that reveals its own affective power.

As historian observers, it seemed that there was much that MINML had in common with oral history practices. There were differences between the project

37 Anna Clark, Private Lives, Public History (Melbourne: Melbourne University Press, 2016), 75-76.

38 Phillips, "Distance and Historical Representation," I34.

39 Age Exchange's film, Meeting in No Man's Land, can be viewed at: https:/www.youtube.com/ watch?v=ZtOvjVihEfA.

40 Mark Salber Phillips, "On the Advantage and Disadvantage of Sentimental History for Life," History Workshop Journal, 65, no. I (Spring 2008): 49-64. See also Michael Roper's discussion of Phillips and the "emotional turn" in "The Unconscious Work of History," Cultural and Social History II, no. 2 (2014): 169-93. 
and more traditional reminiscence work, for example, the age of many of its subjects and the filmed rather than theatrical output. Categorizing MINML would not be a fruitful task: it was a unique project in its merging of oral history and reminiscence, documentary film format, collective nature, and international dimension. It was challenging to observe because the group processes were so immersive. On occasion it felt that the affective power released was overwhelming, telescoping the distance between us and the contributors and making it harder to capture what happened and form insights. Fundamentally, it is this factor of distance that differentiates MINML from the usual forms of history with which we are more familiar. For the historian, the physical interview is a critical part of the process, but it is only a part, and one that is subsequently reviewed and compared with others in a broader context. The meanings made are products not just of the interviews, but of secondary research and the interpretive effort brought to bear upon them, that is, analytical work undertaken at an emotional and temporal distance from the primary material. MINML was a community of powerful feelings that was, in many ways, an end in itself. The film lives on as a potent record of the project, if not an interrogation of the motivations that drew people into it. MINML was a unique project; it operated in its own space drawing on different practices and approaches, making it a wholly fascinating indicator of the national and family intersections in the legacies of the First World War.

We are grateful to the AHRC First World War Commemoration Centre and to "Everyday Lives in War" at the University of Hertfordshire for funding our engagement with the project. Thanks are also due to the colleagues who kindly read and commented upon drafts of this article, including David Savill, Sarah Lloyd, and Julie Moore. We are also very grateful to the anonymous reviewers of the initial draft whose insightful comments have allowed us to develop further our understanding of the project, its participants, and outputs.

Rachel Duffett is a teaching and research fellow and Michael Roper a professor at the University of Essex in England. They have both published extensively on the British soldiers' material and emotional experience of the First World War and are currently working on a project that explores the legacy of the conflict in domestic life and its impact on the children who grew up in its shadow. 